Lutz Schirrmeister - Christine Siegert

Victor V. Kunitzky • Pieter M. Grootes

Helmut Erlenkeuser

\title{
Late Quaternary ice-rich permafrost sequences as a paleoenvironmental archive for the Laptev Sea Region in northern Siberia
}

Received: 29 September 1999 / Accepted: 7 February 2001 / Published online: 9 June 2001

(C) Springer-Verlag 2001

\begin{abstract}
Ice-rich permafrost sequences with large polygonal ice wedges represent excellent archives for paleoenvironmental reconstruction. Such deposits contain numerous well-preserved records (ground ice, paleosols, peat beds, different types of fossils), which permit characterization of environmental conditions during a clearly defined period of the past $60 \mathrm{ka}$. Based on field investigations carried out within framework of the German-Russian project "Laptev Sea System 2000" on the Bykovsky Peninsula (SE of the Lena Delta) results from cryolithological studies, sedimentological analyses, as well as new radiocarbon data are presented. For the first time it is shown that the Ice Complex accumulated without significant interruptions from approximately 60 k.y. B.P. until the end of the Pleistocene. Geochemical data (total organic carbon, $\mathrm{C} / \mathrm{N}, \delta^{13} \mathrm{C}_{\mathrm{org}}$ ) and the mass-specific magnetic susceptibility clearly show changing environmental conditions from stadial to interstadial times in the Late Pleistocene and during the transition to the Holocene. These results permit us to reconstruct the development of an Arctic periglacial landscape in the coastal lowland during Ice Complex formation in the Late Quaternary. This evolution coincided generally with the global environmental trend up to marine isotope stage 4 .
\end{abstract}

L. Schirrmeister $(\bowtie) \cdot$ C. Siegert

Alfred Wegener Institut for Polar and Marine Research,

Telegrafenberg A43, 14473 Potsdam, Germany

E-mail: lschirrmeister@awi-potsdam.de

Phone: +49-331-2882157

V.V. Kunitzky

Permafrost Institute, Russian Academy of Science,

Siberian Branch, Yakutsk-18677018, Sakha (Yakutia), Russia

P.M. Grootes · H. Erlenkeuser

Leibniz Laboratory, Christian-Albrecht-University,

Max-Eyth-Strasse 11, 24098 Kiel, Germany
Keywords Late Quaternary · Paleoenvironment · Permafrost deposits $\cdot$ Peat $\cdot$ Thermokarst $\cdot$ Siberian Arctic $\cdot$ Laptev Sea $\cdot$ Radiocarbon dating

\section{Introduction}

Contrary to areas in the western part of the Eurasian North, which were affected by continental glaciation during the Pleistocene, the large lowlands of Northeast Siberia were probably never covered by an ice sheet (Alekseev 1982). The continuous existence of permafrost since the early Middle Pleistocene is evident (Kaplina 1982). Under the severely continental cold climate of this region the thickness of permafrost reaches more than $600 \mathrm{~m}$ (Embleton and King 1975).

Extremely ice-rich and perennially frozen sediment sequences with thick polygonal ice wedges, called "Ice Complex", were formed in territories acting as terrestrial accumulation basins during the Late Pleistocene. Subaerially exposed most of the time, such sediments froze as permafrost more or less synchronously with accumulation. Numerous plant and animal fossils, as well as geochemical properties of the sediments, which characterize the environmental conditions during particular time intervals, were quite well preserved by this syngenetic freezing.

The formation of ice wedges is initiated by deep frost cracking associated with intense cooling and thermal contraction of exposed sediments in the Arctic winter. The cracks fill progressively with ice frozen from melting snow during spring. Ice wedges form polygonal patterns, and they grow in accumulation areas with a permafrost table close to the surface, synchronous with the deposition and freezing of sediments.

The Ice Complex is widely distributed in northern Siberia, especially in the coastal lowlands adjacent to the Laptev and East Siberian seas (Romanovsky 
1993). Permafrost sequences similar to the Ice Complex occur also in Arctic and Subarctic regions of North America. However, in contrast to Siberia, they are restricted to limited areas in the coastal lowlands of the Mackenzie and Yukon river basins where the Ice Complex is located (French 1996). Moreover, such deposits are usually less thick and the ice wedges are smaller. It is inferred that during the Late Pleistocene the influence of the Wisconsin ice sheet led to the restricted distribution of ice-rich permafrost in Arctic and Subarctic regions of North America (French and Heginbottom 1983).

Despite numerous investigations of the Siberian Ice Complex, its genesis and age are largely unknown. Although polygonal ice wedges are evident in deposits of Early and Middle Pleistocene age (Kaplina 1982), it seems that extremely ice-rich deposits of the Ice Complex were widely spread only during the Weichselian glacial period (Romanovsky 1993). However, we do not have enough age determinations from the Ice Complex to cover the whole Late Pleistocene. While numerous age data are obtained from deposits belonging to Middle Weichselian times, accumulation of Ice Complex deposits during the Last Glacial Maximum (LGM) is hardly evident up to now (Vasil'chuk and Vasil'chuk 1997).

Most popular among concepts dealing with Ice Complex genesis are the fluvial (Popov 1953; Katasonov 1954; Rozenbaum 1981), aeolian or cryogenicaeolian (Tomirdiaro et al. 1984; Tomirdiaro and Chernenky 1987), and polygenetic (Sher et al. 1987), concepts. Besides this, the Ice Complex is regarded to be composed of proluvial and slope sediments by Gravis (1969), Slagoda (1991, 1993, especially for the Bykovsky Peninsula), and other researchers. According to Eliseev (1977) proluvial deposits formed in piedmont areas by periodic runoff from mountains. Such deposits grew to significant thickness and spread under arid climate conditions. According to Galabala (1987, 1997) and Kunitsky (1989, especially for the Bykovsky Peninsula), meltwater activities from perennial snowfields are of great importance for the formation of the Ice Complex. Grosswald (1998) assumed that the Ice Complex is formed in ice-dammed lakes in front of shelf glaciers. In contrast, Nagaoka et al. (1995) considered the ice-rich permafrost sequence on the Bykovsky Peninsula to be deposits of the Lena Delta.

To use the great potential of the Ice Complex as a paleoenvironmental archive, reliable age data and more detailed information on the conditions of the formation of these deposits are needed. Therefore, one of the basic aims of the multidisciplinary research project "Paleoclimate signals in ice-rich permafrost" is to establish a better age model for the selected key section of the Ice Complex in northern Siberia. The research program includes cryolithological and sedimentological studies of permafrost deposits, investigation of ground ice by stable isotope and hydrochemi- cal analyses, paleontological research of mammals and beetles, palynological and carpological studies and age determinations (Siegert et al. 1999). This paper reports on first results of cryolithological field research, radiocarbon dating, and geochemical investigations of the sediments.

\section{Study area}

The Bykovsky Peninsula is located northeast of the town of Tiksi and extends between $71^{\circ} 40^{\prime}-72^{\circ} \mathrm{N}$ and $129^{\circ}-129^{\circ} 30^{\prime}$ E (Figs. 1, 2). The Peninsula's modern shape is a result of intense thermokarst processes which developed on the Ice Complex surface during the Holocene. A well-subdivided landscape with numerous lakes within thermokarst depressions (alasses) and thermo-erosional channels characterize this territory (Fig. 2).

Figure 3 shows the working area in detail. Relic lakes of a former larger thermokarst lake and a pingo are located within the thermokarst depression (alas). Ice-wedge polygons cover the bottom of this depression. The Ice Complex reaches an altitude of $+40 \mathrm{~m}$ above sea level. Its surface is dissected by numerous thermo-erosional valleys and in places takes the form of small young thermokarst lakes.

The study location "Mamontovy Khayata" and its adjacent territory, which has been studied by Arctic scientists since the nineteenth century (Bunge 1895), was selected for our investigations. It was also an important location for permafrost research during the past two decades (Tomirdiaro and Chernenky 1987;

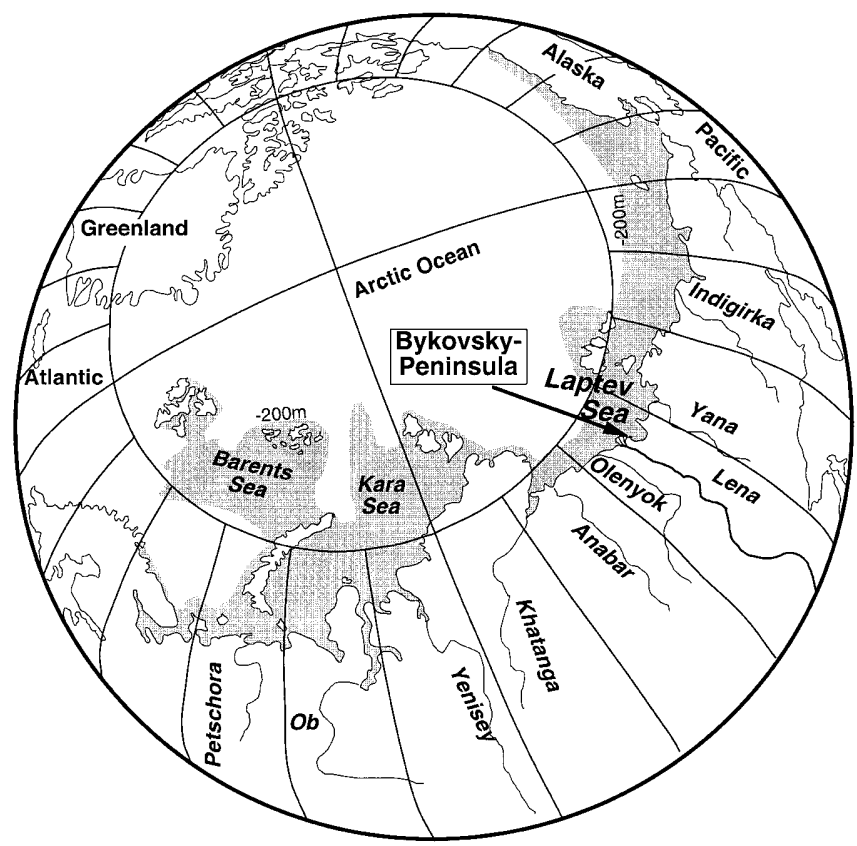

Fig. 1 The location of the study area (Bykovsky Peninsula) in the Siberian Arctic southeast of the Lena Delta and its relation to the Laptev Sea shelf area of the Arctic Ocean 


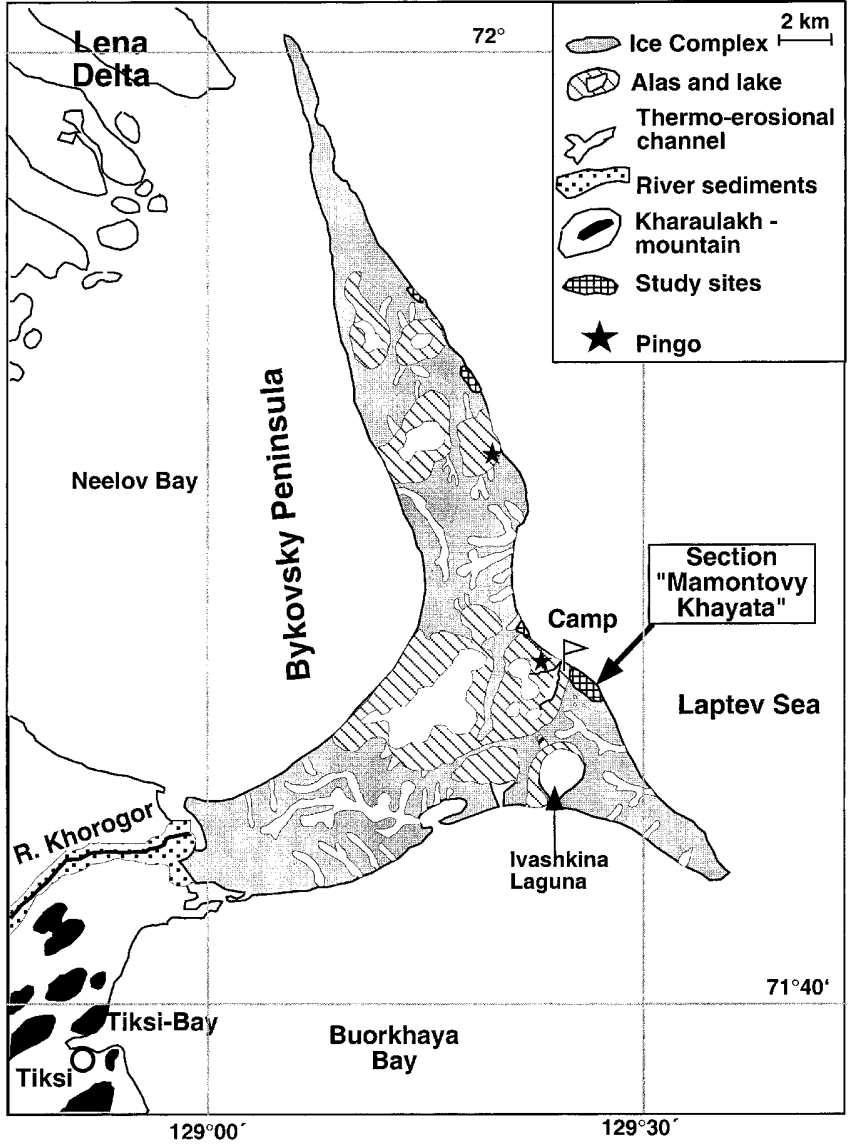

Fig. 2 Sketch of the Bykovsky Peninsula with typical geomorphological units of the thermokarst relief and the positions of the study sites. (After Grigoryev 1993)

Kunitsky 1989; Slagoda 1991, 1993; Grigoryev 1993; Fukuda 1994; Nagaoka 1994).

\section{Materials and methods}

Sediments were studied mainly in the large coastal outcrops at the site "Mamontovy Khayata" (Fig. 3). The intrapolygonal sediment blocks of the Ice Complex remain here in the form of thermokarst mounds after melting of the surrounding ice wedges and thermoerosion. As the cores of most thermokarst mounds are perennially frozen, the study and sampling of the ice-rich sediments was feasible. Therefore, we are able to combine the elements of an entire profile of the Ice Complex. In addition, sediments of associated thermokarst deposits were sampled.

During field studies the cryofacies analysis (Katasonov 1978) was used. This method is based on the relationship between the cryogenic construction of sediments and the facial conditions of accumulation and freezing. Firstly, the cryogenic construction is characterized by the ice content as quantitative parameter. The ice content was determined by the weight of ice in the frozen sample in relation to the dry sediment and is expressed as mass percentage. Secondly, the cryostructure of sediments (i.e., distribution, size, and morphology of segregated ice) were described. Thirdly, specific features of the sediment formation caused by different cryogenic processes, such as cryoturbation, frost cracking, and short-term thermokarst, are given. All these properties yield information in particular on the hydrological

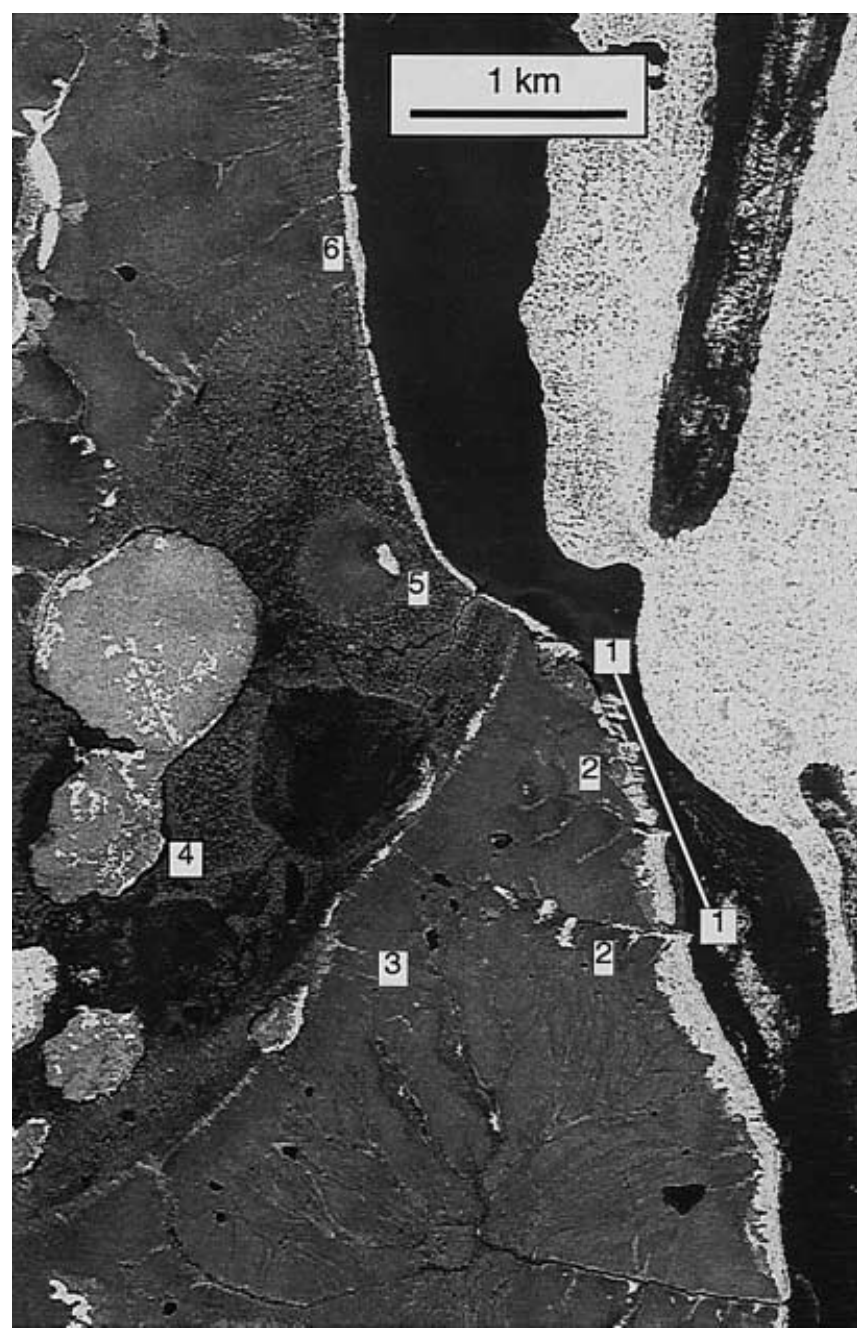

Fig. 3 Detail of a satellite picture of the Bykovsky Peninsula (Corona satellite, June 1964) shows the Ice Complex elevation and the alas thermokarst depression on the shore of the Laptev Sea. 1 Ice Complex with the outcrop "Mamontovy Khayata"; 2 Thermo-erosional valleys; 3 Small recent thermokarst lakes; 4 alas depressions with ice-covered lakes and alluvial swamps; 5 Pingo "Mamontovy Bulgunyakh" with a snow patch; 6 alas terrace (thermo-terrace)

and thermal conditions under which perennially frozen sediments formed. In addition, the cryostructure is influenced by sediment properties such as grain size, clay mineral composition, organic matter content, and composition. The assemblage of cryostructures can be used to establish a cryostratification of permafrost sequences, because their changes may indicate variations in the environmental conditions and thus in the character of cryogenic processes (French 1996).

Most of the age determinations were carried out by radiocarbon. Accelerator mass spectrometry (AMS) at the Leibniz Laboratory for Radiometric Dating and Stable Isotope Research, Kiel University (Germany). The larger samples from autochthonous peat beds and peat inclusions in soil horizons were dated by conventional radiocarbon analysis at the same laboratory and at the Laboratory of the Permafrost Institute, Yakutsk (Russia). Plant remains, which according to their appearance had not been redeposited (grass roots, peat moos twigs, twigs of dwarf shrub with bark), were selected under the microscope for AMS dating. The details of the Leibniz Laboratory AMS procedures 
are given by Nadeau et al. (1997) and Nadeau et al. (1998). Only the ${ }^{14} \mathrm{C}$ AMS ages of the extracted residues free of humic acids were used for age interpretation. ${ }^{13} \mathrm{C} /{ }^{12} \mathrm{C}$ ratios of AMS samples were measured simultaneously with the ${ }^{14} \mathrm{C} /{ }^{12} \mathrm{C}$ analysis. Conventionally dated samples (labeled $\mathrm{KI}$ ), mostly peats, were repeatedly washed to remove the abundant clay mineral fraction and were acidified to reject carbonates prior to combustion in an excess of oxygen. The peat samples revealed a considerable amount of ash residue after combustion $(>50 \%)$ and the dating accuracy occasionally suffered from low net sample size. $\delta^{13} \mathrm{C}$ values were measured on the sample gas on a Finnigan MAT Delta $\mathrm{E}$ gas isotope ratio mass spectrometer. The external precision is better than $0.1 \%$. All ${ }^{14} \mathrm{C}$ ages were normalized for isotopic fractionation based on the ${ }^{13} \mathrm{C} /{ }^{12} \mathrm{C}$ ratio and represent "conventional" ${ }^{14} \mathrm{C}$ ages defined according to Stuiver and Polach (1977). For sample ages exceeding the range of the dating method, a minimum ${ }^{14} \mathrm{C}$ age limit is given at the $95 \%$ confidence level. The conventional ages were converted into calibrated ages using the program CALIB rev. 4.0 and the INTCAL98.C14 calibration data (Stuiver et al. 1998).

Geochemical parameters as well as the magnetic susceptibility of samples were determined in order to investigate the variation in the conditions of accumulation and post-sedimentary transformation of sediments. The total carbon content and the content of organic carbon of the decarbonated samples were determined using a CS-Autoanalyzer (ELTRA CS 100/1000 S). The analysis of the carbonate content was carried out gas-volumetrically by means of the Scheibler apparatus. The total nitrogen and sulfur contents were measured with a CNS Microanalyzer (LECO 932). Bartington MS2 and MS2B instruments were used to determine the mass-specific magnetic susceptibility. The $\delta^{13} \mathrm{C}$ values of bulk organic carbon were determined on decarbonated samples by high-temperature combustion in a Heraeus Elemental Analyzer coupled with a Finnigan MAT Delta $\mathrm{S}$ mass spectrometer. The $\delta^{13} \mathrm{C}$ values are expressed in \%o vs PDB with a precision better than $0.2 \%$. All these analyses were carried out in the Laboratories of the Alfred Wegener Institute in Potsdam (Germany).

\section{Results of cryolithological field studies}

At the coastal cliff "Mamontovy Khayata" and adjacent areas, three genetic units corresponding to distinct geomorphological elements are exposed. The Ice

Fig. 4 Profile of the coastal cliff "Mamontovy Khayata", Bykovsky Peninsula, showing the relationships and positions of different permafrost deposits
Complex - extremely ice-rich deposits ( $>40 \mathrm{~m}$ thick) with large ice wedges - represents the main part of the profile. The Ice Complex is bound laterally by deposits of an alas depression and is covered by sediments probably formed by thermo-erosional processes (Fig. 4).

\section{Ice Complex deposits}

The Ice Complex deposits consist of grey, ice-rich, slightly carbonate silty to fine-grained sands. Based on the intensity of pedogenic processes, as well as on the content of plant remains, three different levels within the Ice Complex unit are distinguished. A relatively small amount of plant remains and weakly displayed pedogenic features characterize sediments of the lower part near sea level. In contrast, deposits of the middle level $(+10$ to $+25 \mathrm{~m})$ include numerous peaty paleosols and distinctly more plant remains (shrub branches, twigs, grass roots, moss remains). A peat lens of approximately $1 \mathrm{~m}$ thickness occurs in places between these two levels. The lower and the middle level of the Ice Complex are separated by a thermoterrace, where Ice Complex deposits are transformed by modern thermal erosion and soil formation; therefore, the lower level is only visible at the modern abrasion edge near the shore.

Fifteen buried peaty soils could be distinguished within the middle level. Peaty layers are noticeably more resistant to thermal erosion than mineral horizons (Fig. 5). Generally, such a paleosol is $10-20 \mathrm{~cm}$ thick, brown-spotted, peaty, and cryoturbated. It contains shrub remains and often fine, vertically orientated grass roots. The upper level of the Ice Complex is preserved only in the central part of the outcrop between +25 and $+39 \mathrm{~m}$ and consists mainly of ice-rich silt. The whole upper level of the Ice Complex forms a steeper bank than does the middle. This is explained by both the low content of peaty material and the extreme thickness of the ice wedges in these deposits. On top of this unit a 1- to 2-m-thick sandy cover and a peaty horizon are found. The uppermost sediments

s

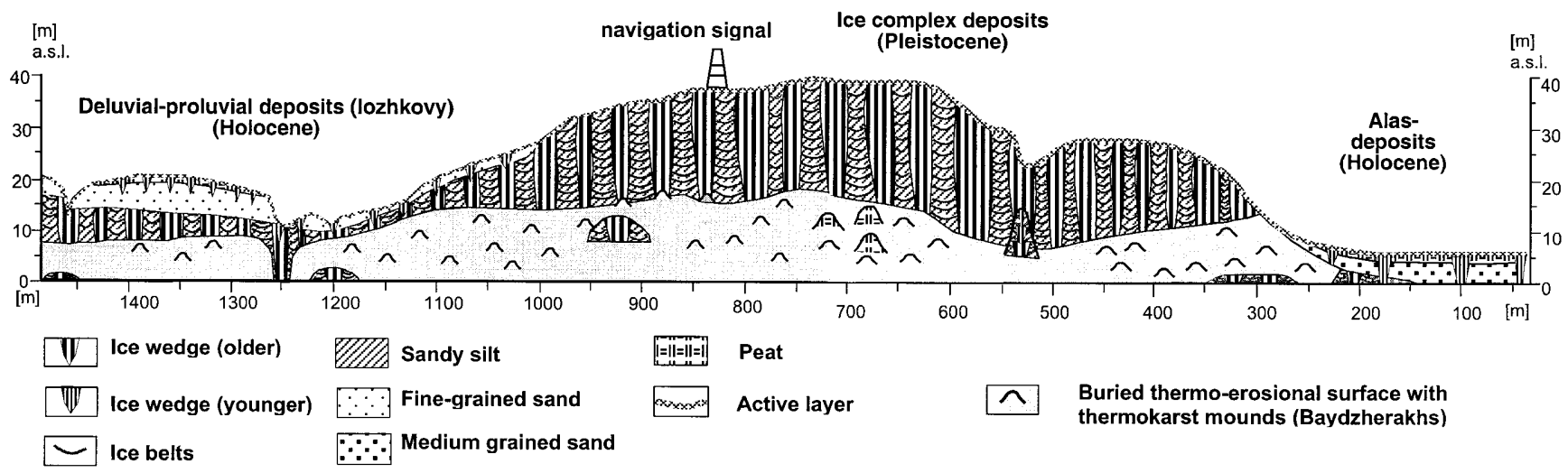




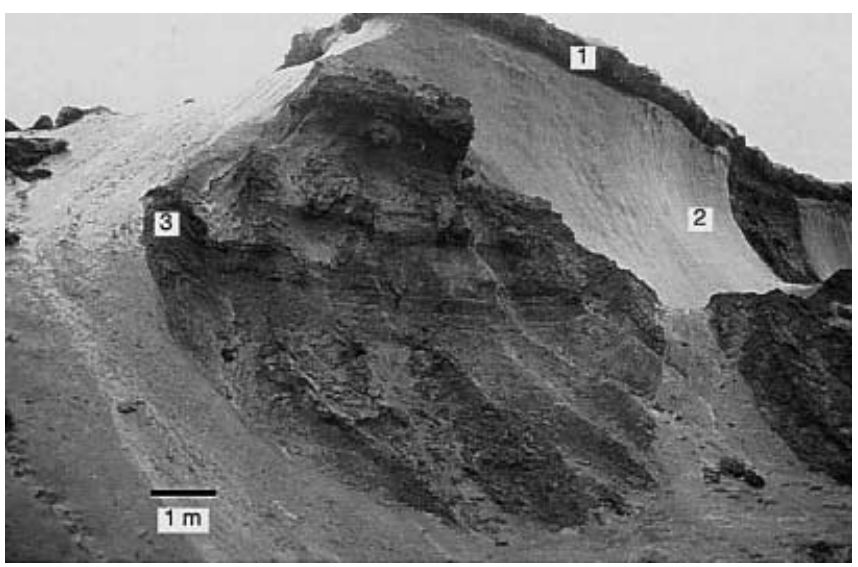

Fig. 5 Intrapolygonal sediment column (thermokarst mound; Russian: baydzharakh) of the upper Ice Complex level $(15-25 \mathrm{~m})$ with cryoturbated paleosol horizons and peat inclusions. 1 Active layer; 2 ice wedge; 3 horizontal edge of peaty paleosol

contain cryoturbated horizons with small sand wedges of approximately $20 \mathrm{~cm}$ in length.

Paleosols differ clearly in cryostructure and ice content from sediment horizons that have only been slightly influenced by the pedogenesis. While the soil horizons, which are enriched with organic matter, are characterized by a fine lens-like or lens-like reticulated cryostructure and by ice contents of $60-110 \%$, sediment interlayers between these horizons have higher ice contents (100-180\%) and show a typical banded cryostructure. This structure consists of more or less pure ice bands of approximately $1-10 \mathrm{~cm}$ thickness alternating with sediment interlayers showing a fine to coarse lens-like reticulated cryostructure. The layered cryostructures show upward-bent flexures in contact with the ice wedges in all positions of the study site.

\section{Deposits in the thermokarst depression}

Alas deposits were investigated in a coastal outcrop in the southern marginal zone of the alas depression by coring on top of the pingo and under a terrace at the northern alas margin (Fig. 3). At the first site, alas deposits ( $>3 \mathrm{~m}$ thick) with smaller ice wedges discordantly overlie the Ice Complex (Fig. 4). Alas sediments in the investigated profile consist of mediumto coarse-grained sands with relatively low ice contents $(58-80 \%)$ and a massive or fine lens-like cryostructure. The cross-bedded sands contain fossil wood and a rooted allochthonous peaty horizon. The sandy alas deposits are overlain by a peat bed of approximately $1 \mathrm{~m}$ thickness.

Sediments on top of the pingo were studied by core drilling. They consist of dense sandy silt with a lower ice content (15-30\%). Very fine broken ice lenses determine the cryostructure. Cross-bedded lacustrine sands and layers with allochthonous plant remains occur in this profile. The ice core of the pingo was reached at a depth of $6.5 \mathrm{~m}$ below the surface.

The terrace of the third site consists of strongly deformed silts and sands rich in plant fossils. According to Ivanov (1984), these formations are explained as a thermo-delapsed (collapsed) permafrost deposit. A layer of larch stumps was found with diameters of approximately $10-15 \mathrm{~cm}$.

\section{Deposits in a thermo-erosional valley}

Sandy sediments of approximately 3-5 m thickness have accumulated in a wide runoff valley near the top of the Ice Complex (Fig. 4.). They overlay the Ice Complex deposits with a clear erosional discordance. The wide valleys' margins are filled with slope sediments, strongly deformed by solifluction in which numerous plant fossils are included. In parts, the sandy valley deposits are covered by an autochthonous peat horizon.

\section{Age determination}

Twenty datings are available from the literature for the "Mamontovy Khayata" section and the adjacent thermokarst depression. Most of the radiocarbon data pertain to the relatively thick peat horizon in the middle part of the section (Kunitsky 1989; Slagoda 1993). They concentrate between 28 and 33 k.y. B.P., but one radiocarbon age of $22.20 \pm 0.93$ k.y. B.P. (IM-748) was also obtained. For the lower part of the Mamontovy Khayata cliff (below $+15 \mathrm{~m}$ ) radiocarbon ages generally exceed 45 k.y. B.P. This result was corroborated by a thermoluminescence age of $54 \pm 13$ k.y. B.P. (RTL-761). Five radiocarbon ages from the upper part of the Ice Complex range from $20.835 \pm 150$ years B.P. (IM-749) to $28.300 \pm 370$ years B.P. (NUTA-2839); however, the exact position of some samples is dubious (Nagoaka 1994; Nagoaka et al. 1995). Peats in the alas sections are dated at approximately 9 k.y. B.P. and peats at the top of the Ice Complex range from 11 to 3 k.y. B.P.

The new radiocarbon ages are listed in Tables 1 and 2. The dated plant material seems to have been deposited in situ in most cases. A few ages date plant material of the lower level of the Ice Complex. These deposits exposed near the shore line exhibit ages of 50 k.y. B.P. or higher. As these ages are close to or exceed the dating limit of the radiocarbon method, the analytical uncertainties are high. However, the datings fit closely to the general age-altitude relation extrapolated from above. The middle level of the Ice Complex encloses numerous horizons of paleo-cryosols. They cover a period between 50 and 28 k.y. B.P., i.e., they were formed during the Middle Weichselian period. A peat horizon of approximately 1-m thickness 
Table 1 Radiocarbon dates of plant remains from deposits of the Ice Complex on the "Mamontovy Khayata", Bykovsky Peninsula (Laboratories: KI, KIA Leibniz Laboratory, Kiel, Germany; PI, Permafrost Institute, Yakutsk, Russia) $A M S$ accelerator mass spectrometry

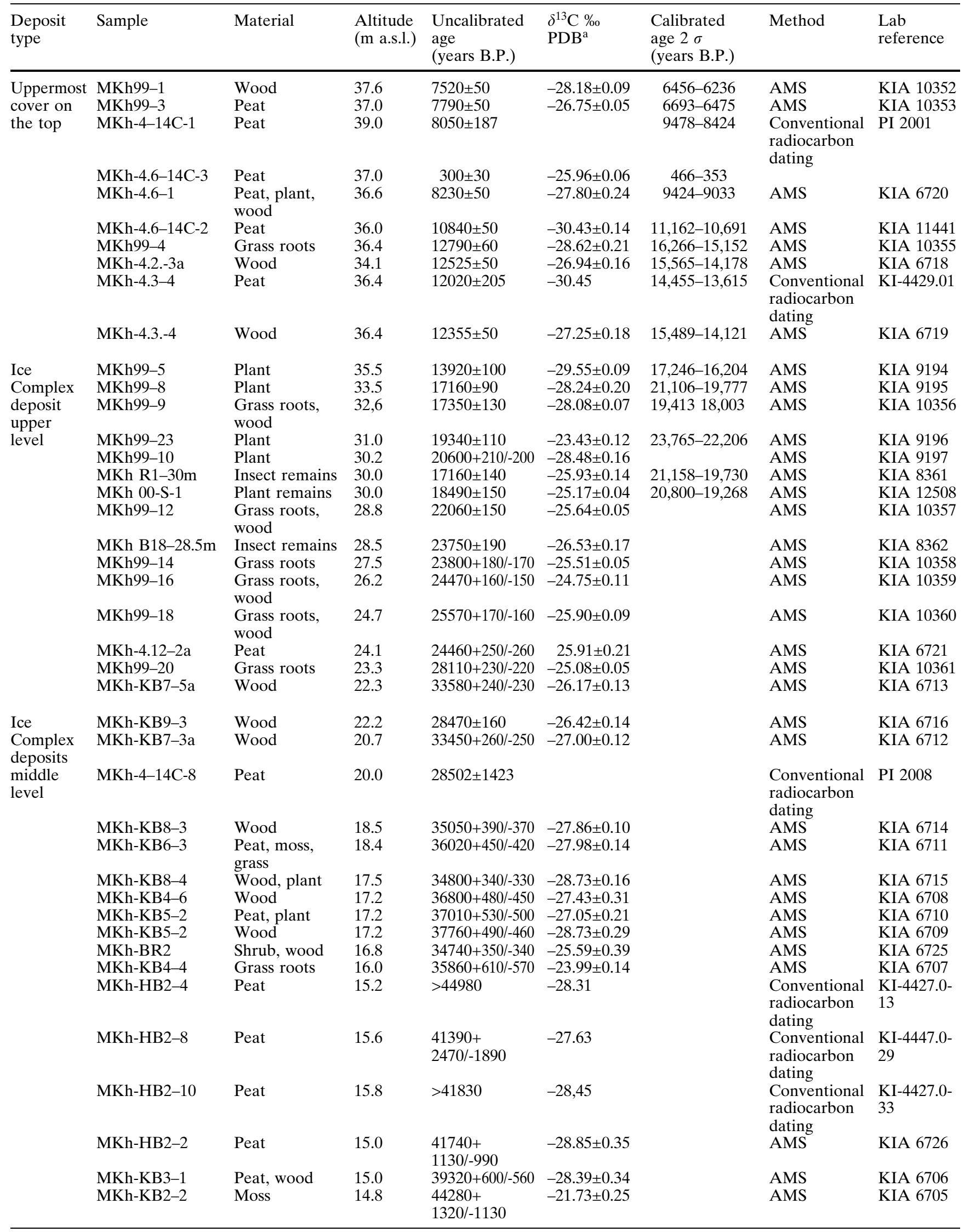


Table 1 (continued

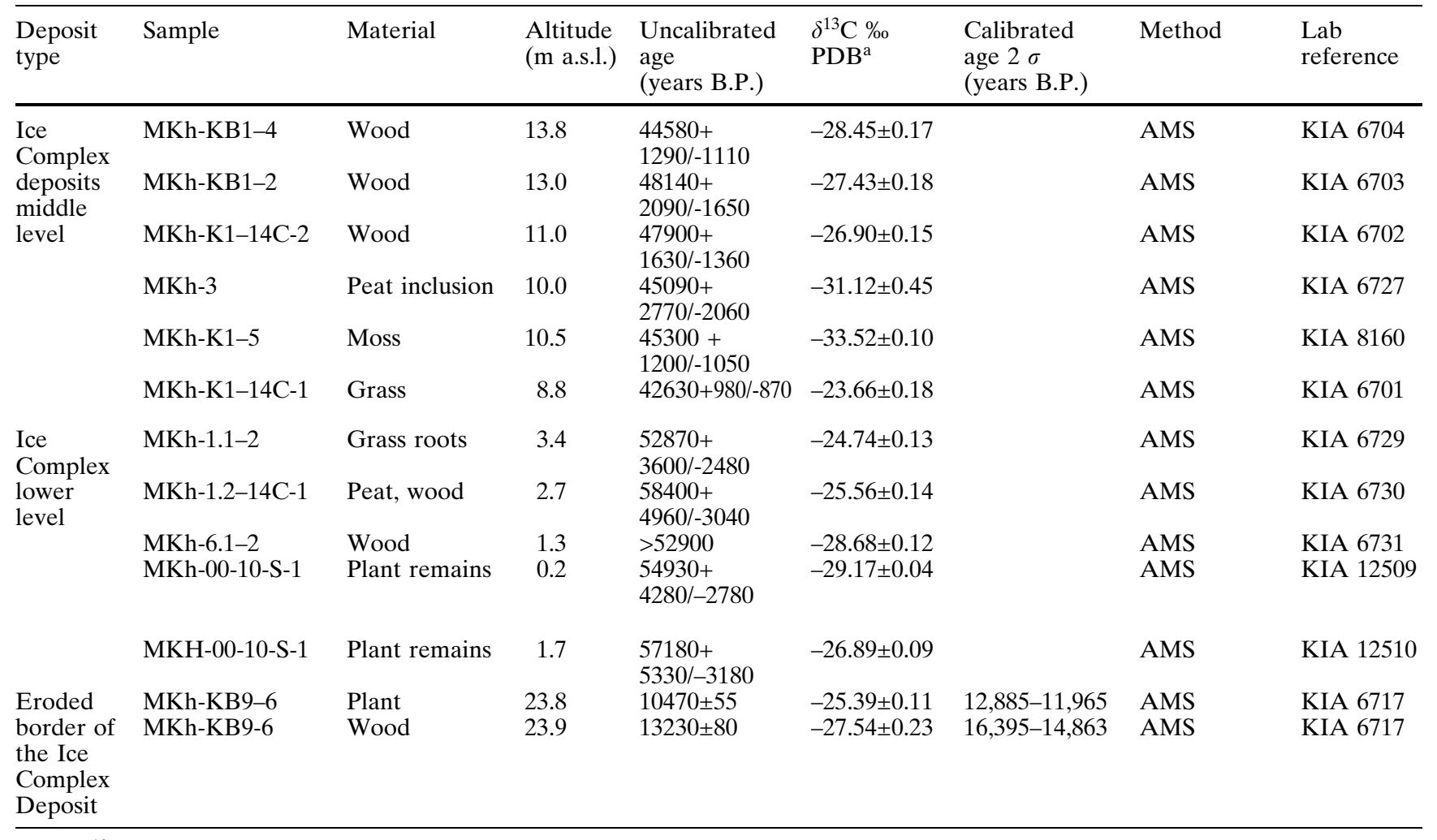

${ }^{a}$ The $\delta^{13} \mathrm{C}$ values include the effects of fractionation during graphitization and in the AMS system, and therefore cannot be compared with $\delta^{13} \mathrm{C}$ values obtained per mass spectrometer on $\mathrm{CO}_{2}$

$(+15 \mathrm{~m})$ within this level was dated at approximately 40 k.y. B.P. Ages of 25 to 12 k.y. were determined for plant material in the upper level of the Ice Complex (Table 1). Accumulation thus clearly continued also during the Last Glacial Maximum.

If all radiocarbon ages of plant materials from the Ice Complex are plotted against altitude, a continuous age sequence ranging between 60 and $12 \mathrm{k} . \mathrm{y}$. B.P. emerges for the whole section studied - from sea level to the highest Ice Complex elevation (Fig. 6). A small gap buried under slope sediments between +4 and + $9 \mathrm{~m}$ altitude corresponds to ages of approximately 55 to 50 k.y. B.P.; however, a jump in age of approximately $15 \mathrm{k} . \mathrm{y}$. between +22 and $+24 \mathrm{~m}$ (Table 1 ) could have been caused by erosional processes in an old thermo-cirque on the northern slope of the Ice Complex (Sher et al. 2000).

Peat and plant material of more sandy deposits which overlay the Ice Complex were dated at approximately 12 to 8 k.y. B.P. Marginal slope sediments in a thermo-erosional valley (Fig. 4) have ages of 4.4 and 1.4 k.y. B.P., whereas the peat layer above the valley deposits was formed in the past 1000 years (Table 2). Ages of 13.5 to 7.3 k.y. B.P. were measured for plant materials included in sandy deposits in the southern marginal zone of the alas (Fig. 4). Here, a 4- to 3-k.y.-B.P.-old peat horizon covers the alas sands. Plant remains under a terrace at the northern alas margins show ages of between 5 and 10 k.y. B.P. (Table 2).

\section{Sediment properties}

The samples of all sediment types selected in the field on the basis of their geomorphological situation, sedimentological and cryogenic features, as well as their fossil content were analyzed for the following properties: total organic carbon content (TOC); carbonate content; $\mathrm{C} / \mathrm{N}$ ratio; and stable isotope composition of the bulk organic carbon $\left(\delta^{13} \mathrm{C}_{\text {org }}\right)$. In addition, the mass-specific magnetic susceptibility of all samples was measured. The Ice Complex sequence could be subdivided into four units based on some of these characteristics (TOC, C/N, $\delta^{13} \mathrm{C}$; Fig. 7). Variations of the sediment properties of the Holocene deposits in thermo-depressions and thermo-erosional valleys are more difficult to categorize since they consist mainly of reworked material from different horizons of the Ice Complex; therefore, we concentrate on the undisturbed sequences of the section "Mamontovy Khayata."

As shown in Fig. 7, the TOC content in deposits of the lower level $(0-+4 \mathrm{~m})$ and the upper level $(+23$ to + $35 \mathrm{~m}$ ) is low and varies between 2 and $3 \%$. In contrast, the TOC content in deposits of the middle level 
Table 2 Radiocarbon dates of plant remains from permafrost deposits associated with the Ice Complex in the surroundings of the "Mamontovy Khayata", Bykovsky Peninsula (Laboratories:

\begin{tabular}{|c|c|c|c|c|c|c|c|c|}
\hline $\begin{array}{l}\text { Deposit } \\
\text { type }\end{array}$ & Sample & Material & $\begin{array}{l}\text { Altitude } \\
\text { (m a.s.l.) }\end{array}$ & $\begin{array}{l}\text { Uncalibrated } \\
\text { age } \\
\text { (years B.P.) }\end{array}$ & $\begin{array}{l}\delta^{13} \mathrm{C} \% \text { \% } \\
\mathrm{PDB}^{\mathrm{a}}\end{array}$ & $\begin{array}{l}\text { Calibrated } \\
\text { age } 2 \sigma \\
\text { (years B.P.) }\end{array}$ & Method & $\begin{array}{l}\text { Lab } \\
\text { reference }\end{array}$ \\
\hline \multirow[t]{4}{*}{$\begin{array}{l}\text { Alas } \\
\text { terrace }\end{array}$} & Mbs 0.8 & Peat & 8.0 & $5316 \pm 193$ & & $6487-5907$ & $\begin{array}{l}\text { Conventional } \\
\text { radiocarbon } \\
\text { dating }\end{array}$ & PI 1999 \\
\hline & Mbs 2.5 & Wood & 6.5 & $9443 \pm 242$ & & $11,258-10,174$ & $\begin{array}{l}\text { Conventional } \\
\text { radiocarbon } \\
\text { dating }\end{array}$ & PI 2000 \\
\hline & MB-1.1-2 & Wood & 3.0 & $9475 \pm 40$ & $-26.53 \pm 0.18$ & $11,064-10,579$ & AMS & KIA 6739 \\
\hline & MKh (MB)-6.3-3 & Grass roots & 1.0 & $2040+45 /-40$ & $-23.32 \pm 0.06$ & $2126-1889$ & AMS & KIA 8162 \\
\hline \multirow[t]{10}{*}{$\begin{array}{l}\text { Alas } \\
\text { deposits }\end{array}$} & MKh-alass-14C-3 & Peat & 3.0 & $4375 \pm 313$ & & 5735-4097 & $\begin{array}{l}\text { Conventional } \\
\text { radiocarbon } \\
\text { dating }\end{array}$ & PI 2003 \\
\hline & MKh-alass-14C-4 & Peat & 3.9 & $3416 \pm 277$ & & $4425-2961$ & $\begin{array}{l}\text { Conventional } \\
\text { radiocarbon } \\
\text { dating }\end{array}$ & PI 2004 \\
\hline & MKh-6.2-8 & Peat & 2.2 & $3000 \pm 75$ & -28.38 & $3382-2957$ & $\begin{array}{l}\text { Conventional } \\
\text { radiocarbon } \\
\text { dating }\end{array}$ & KI-4426 \\
\hline & MKh-6.2-14C-6 & $\begin{array}{l}\text { Base of peat } \\
\text { horizon }\end{array}$ & 2.1 & $2885 \pm 30$ & $-30.23 \pm 0.15$ & $3358-2850$ & AMS & KIA 6736 \\
\hline & MKh-6.2-14C-5 & $\begin{array}{l}\text { Wood remain } \\
\text { (reworked) }\end{array}$ & 1.5 & $7330 \pm 40$ & $-26.12 \pm 0.21$ & $8195-8020$ & AMS & KIA 6734 \\
\hline & MKh-6.2-1 & Moss, grass & 0.8 & $2925 \pm 30$ & $-27.07 \pm 0.10$ & $1258-1006$ & AMS & KIA 11439 \\
\hline & MKh-6.2-14C-3 & $\begin{array}{l}\text { Peaty root } \\
\text { horizon } \\
\text { (reworked) }\end{array}$ & 0.5 & $13560 \pm 80$ & $-27.19 \pm 0.12$ & $16,535-15820$ & AMS & KIA 6735 \\
\hline & MKh-6.2-4 & Twigs grass & 0.4 & $2915 \pm 30$ & $-29.25 \pm 0.14$ & $1256-1002$ & AMS & KIA 11440 \\
\hline & MKh-6.1-14C-6 & $\begin{array}{l}\text { Peat inclusion } \\
\text { (reworked) }\end{array}$ & 1.4 & $2910 \pm 30$ & $-26.30 \pm 0.05$ & $3211-2956$ & AMS & KIA 6733 \\
\hline & MKh-6.1-4a & $\begin{array}{l}\text { Wood, } \\
\text { (reworked) }\end{array}$ & 1.2 & $24090 \pm 110$ & $-27.40 \pm 0.20$ & & AMS & KIA 6732 \\
\hline \multirow[t]{7}{*}{$\begin{array}{l}\text { Valley } \\
\text { deposits }\end{array}$} & MKh-1.6.1-10 & Peat & 18.0 & $1360 \pm 35$ & -29.32 & 1332-1195 & $\begin{array}{l}\text { Conventional } \\
\text { radiocarbon } \\
\text { dating }\end{array}$ & $\begin{array}{l}\text { KI-4428.0- } \\
33\end{array}$ \\
\hline & MKh-1.6.1-4 & Peat & 17.4 & $1220 \pm 60$ & $-29,34$ & $1270-970$ & $\begin{array}{l}\text { Conventional } \\
\text { radiocarbon } \\
\text { dating }\end{array}$ & KI-4428.01 \\
\hline & MKh-1.6-3 & Peat & 17.4 & $1105 \pm 35$ & $-28.72 \pm 0.18$ & $1070-938$ & AMS & KIA 6723 \\
\hline & MKh-1.6-2 & Peat & 17.2 & $1080 \pm 35$ & $-26.04 \pm 0.25$ & 1064-934 & AMS & KIA 6722 \\
\hline & MKh-1.6-14C-6 & Peat & 15.0 & $3616 \pm 250$ & & $4787-3361$ & $\begin{array}{l}\text { Conventional } \\
\text { radiocarbon } \\
\text { dating }\end{array}$ & PI 2006 \\
\hline & MKh-1.7.2-5 & $\begin{array}{l}\text { Wood, peat } \\
\text { inclusion }\end{array}$ & 10.5 & $1400 \pm 60$ & $-29.96 \pm 0.33$ & 14141190 & AMS & KIA 6725 \\
\hline & MKh-4.12-3a & Peat inclusion & 26.0 & $4455 \pm 35$ & $-29.36 \pm 0.07$ & $4874-5291$ & AMS & KIA 8161 \\
\hline
\end{tabular}

${ }^{\text {a }}$ The $\delta^{13} \mathrm{C}$ values include the effects of fractionation during graphitization and in the AMS system, and therefore cannot be compared with $\delta^{13} \mathrm{C}$ values obtained per mass spectrometer on $\mathrm{CO}_{2}$

ranges from 2 to $15 \%$, with a marked change at approximately $+10 \mathrm{~m}$. Similar strong variations of the TOC content (between 2 and 27\%) occur at the uppermost cover between +35 and $+38 \mathrm{~m}$. Higher TOC values are always related to peat layers or peaty soil horizons in these levels. These large variations are in accordance with frequent stages of increased soil formation intensity in the middle Ice Complex level and in the uppermost cover horizon.

The carbonate content shows less differences within the Ice Complex deposits. There is a variation
KI, KIA Leibniz Laboratory, Kiel, Germany; PI, Permafrost Institute, Yakutsk, Russia). $A M S$ accelerator mass spectrometry 


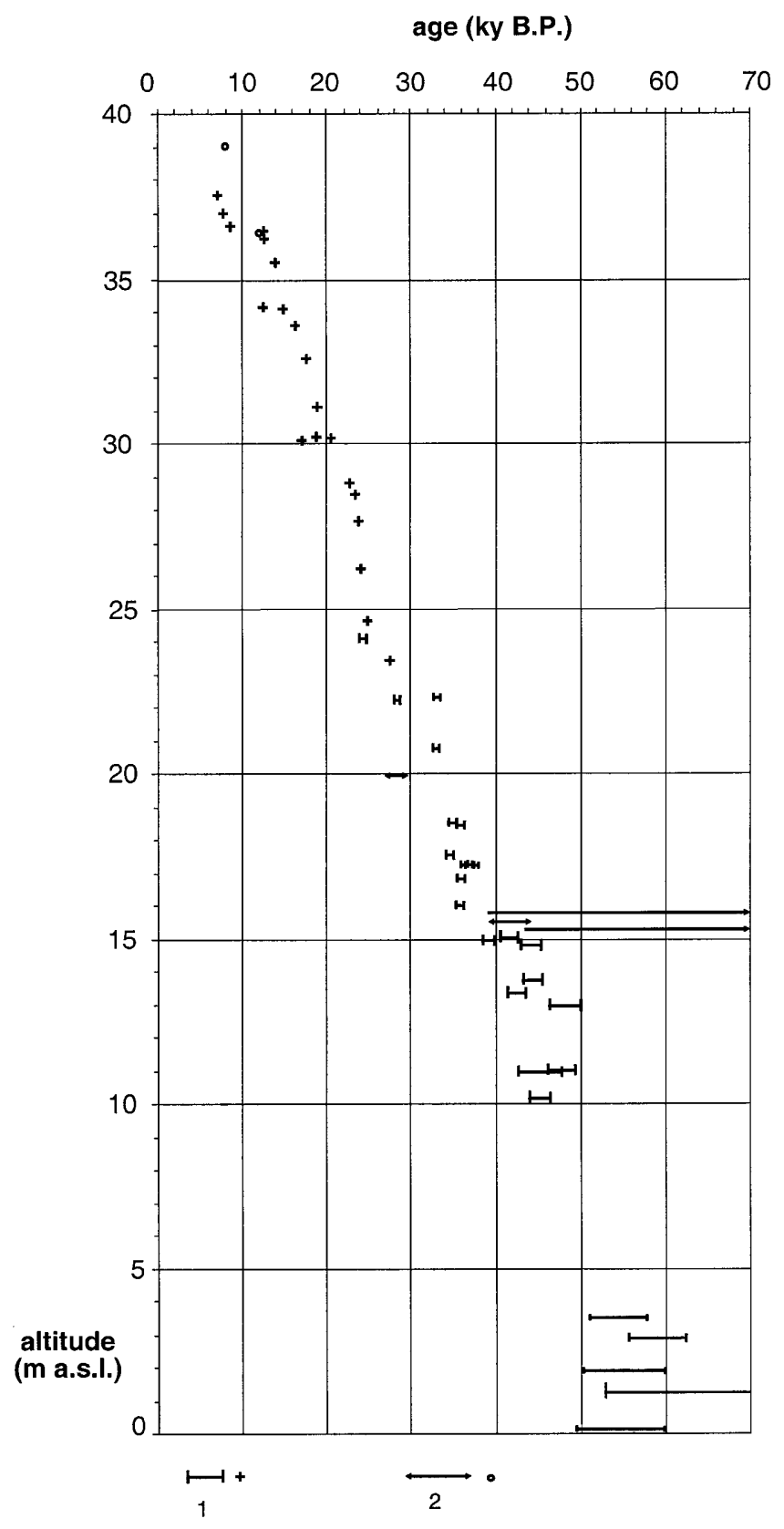

Fig. 6 Radiocarbon dates of plant remains of the Ice Complex deposits and the overlying Holocene cover; outcrop "Mamontovy Khayata" (Bykovsky Peninsula). 1 AMS ${ }^{14} \mathrm{C}$ dates; 2 conventional ${ }^{14} \mathrm{C}$ dates of peat samples

cate a low degree of decomposition in organic matter (Schachtschabel et al. 1992); thus, our results indicate changing degrees of decomposition of the organic matter when comparing mineral layers, peaty soil layers, and peat horizons. Compared with the mineral horizons $(\mathrm{C} / \mathrm{N}=10-12)$ a noticeably lower decomposition characterizes peaty layers $(\mathrm{C} / \mathrm{N}=12-15)$ and the lowest decomposition is found for the peat horizons $(\mathrm{C} / \mathrm{N}=15-23)$. It should be emphasized that the organic matter in deposits of the lower and especially of the upper level of the Ice Complex is more decom- posed $(\mathrm{C} / \mathrm{N}$ ca. 10$)$ than in most deposits of the middle level (Fig. 7). This fact seems to be related to drier conditions and better aeration of the active layer in these levels during deposit formation.

The stable carbon isotope composition of the bulk organic matter can also be used to distinguish sediments from different Ice Complex levels. The $\delta^{13} \mathrm{C}$ values are lowest $(-28.5$ to $-26.8 \%$ o $)$ in peat horizons and in peat inclusions of buried soils in all the units investigated. Disseminated organic matter of mineral interlayers and in soil material between peat inclusions is characterized by a heavier isotopic composition (less negative values). Therefore, large variations of the $\delta^{13} \mathrm{C}$ values from -28.5 to $-25.0 \%$ are observed in the middle level of the Ice Complex $(+10$ to $22 \mathrm{~m})$. More constant and higher (less negative) values of -25.0 up to $-24.0 \%$ are obtained for the upper level $(+22$ to $35 \mathrm{~m})$. The uppermost cover in the Mamontovy Khayata section $(+35-38 \mathrm{~m})$ is again characterized by lower (more negative) $\delta^{13} \mathrm{C}$ values ranging from -26.1 to $-28.8 \%$ o (Fig. 7).

Explanations for $\delta^{13} \mathrm{C}$ value variations in bulk organic matter are still tentative. There are only a few papers on $\delta^{13} \mathrm{C}$ analyses of organic matter in permafrost. Welker et al. (1993, 1995) described the dependence of $\delta^{13} \mathrm{C}$ variations of the cellulose fraction of Dryas octopetula (Rosaceae) and Cassiope tetragona (Ericaceae) in Svalbard (Norway) on season and water supply. High winter precipitations result in more negative values in cellulose grown in summer, although summer temperature and precipitation have no influence. Pfeiffer and Jansen (1993) interpreted differences in $\delta^{13} \mathrm{C}$ values between organic matter of Ice Complex deposits (ca. -23\%o) and thermokarst deposits (ca. $-28 \%$ ) as the results of variously intense decomposition rates under more aerobic or anaerobic conditions. Gundelwein (1998) studied $\delta^{13} \mathrm{C}$ distributions in various soil types in North Siberia. He discovered, firstly, that the $\delta^{13} \mathrm{C}$ values of TOC in dry sites are higher than in wet sites, depending on the $\delta^{13} \mathrm{C}$ values of the corresponding plant associations, and secondly, that increasing $\delta^{13} \mathrm{C}$ values at depths of $5-20 \mathrm{~cm}$ reflect anaerobic transformation of soil organic matter in wet sites.

Bulk sediment samples contain both autochthonous and allochthonous organic carbon; therefore, it is difficult to ascertain the paleoenvironmental conditions only on the basis of variations in $\delta^{13} \mathrm{C}$ values. Nevertheless, the carbon stable isotope composition of the bulk organic matter from the investigated sediments shows trends in agreement with other sediment characteristics (Fig. 7). Considering the results of Gundelwein (1998), the variations in the $\delta^{13} \mathrm{C}$ values of deposits from the middle level probably reflect the presence of a mosaic-like polygonal tundra with moist anaerobic and drier aerobic conditions of soil formation and corresponding plant associations as well as the changes of these conditions with time. The distinct shift to more stable and higher $\delta^{13} \mathrm{C}$ values is recorded 


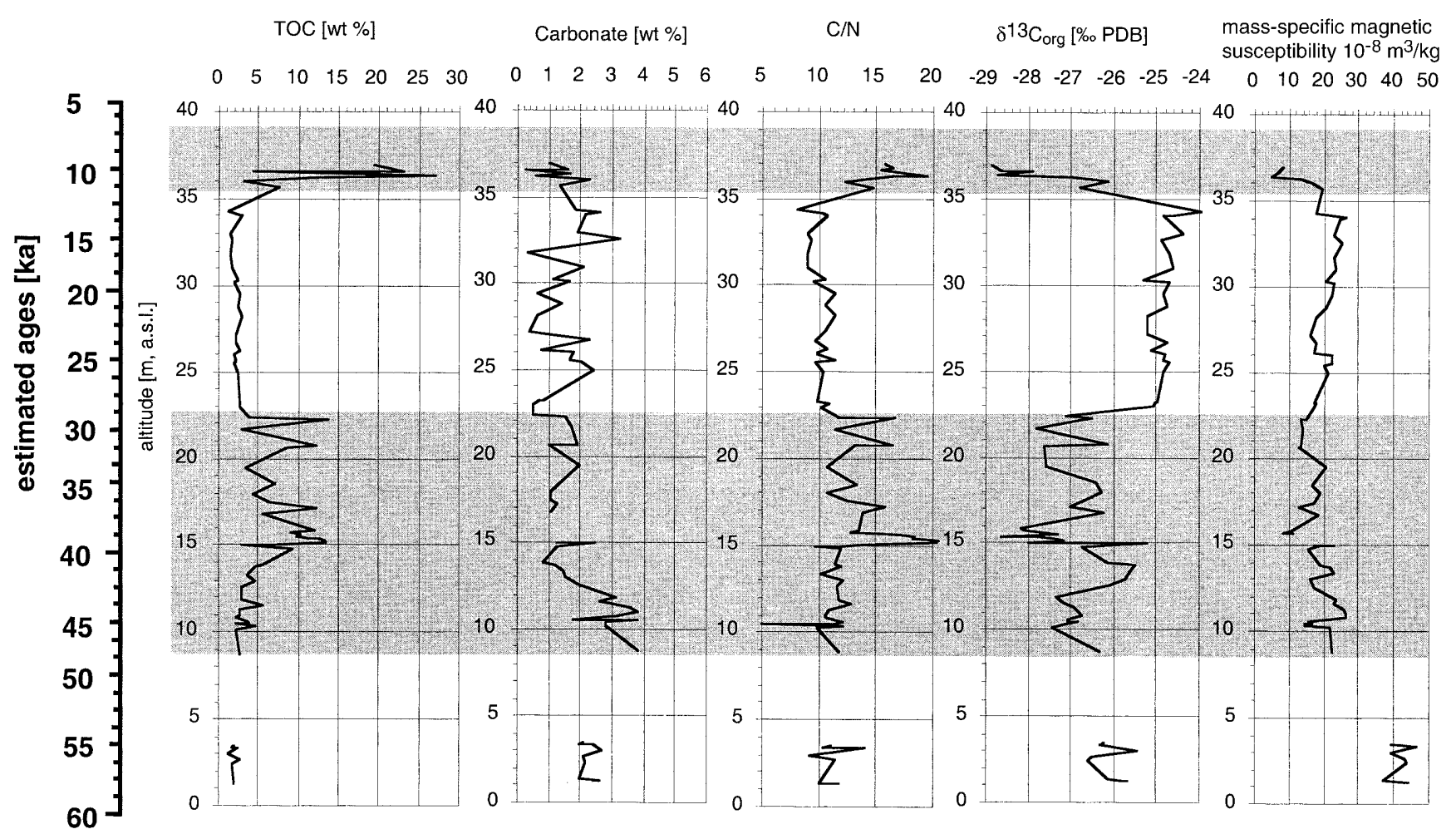

Fig. 7 The analytical basic data (total organic carbon, C/N, carbonate content, $\delta^{13} \mathrm{C}_{\text {org }}$, and mass-specific magnetic susceptibility) of Ice Complex deposits

in deposits of the upper level. Drier and more aerobic conditions during soil formation can be inferred for the upper level based on the low contents of TOC and the slightly increasing values of the magnetic susceptibility in these deposits.

Nevertheless, the variation of $\delta^{13} \mathrm{C}$ values could also be caused by changes in the composition of plant material as well as different isotopic fractionation during the carbon metabolism of the same plant associations. Environmental conditions, such as temperature, humidity, precipitation, and irradiation levels, control both factors (Schliesser 1995). These relationships have not yet been studied in enough detail for arctic permafrost conditions.

The significant decrease in the stable isotope ratio described for the uppermost cover and dated at 12 to 8 k.y. (Fig. 7) seems to be linked to an increase of wetness and resulting peat accumulation at the study site. Meyer et al. (2000) reports a comparable shift in deuterium and oxygen isotope ratios in the ice wedges for the Late Pleistocene Holocene transition.

Measurements of the mass-specific magnetic susceptibility of the Ice Complex confirm the division of the investigated section as presented herein. The magnetic susceptibility of samples from the lower level ranges from 37 to $46 \times 10^{-8} \mathrm{~m}^{3} / \mathrm{kg}$, whereas sediments in the overlying part show values between 10 and $25 \times 10^{-8} \mathrm{~m}^{3} / \mathrm{kg}$. Within the upper part of the section the lowest values of specific magnetic susceptibility $\left(<15 \times 10^{-8} \mathrm{~m}^{3} / \mathrm{kg}\right)$ are obtained for deposits with high organic matter contents (Fig. 7), which are influenced mostly by soil formation.

As shown elsewhere, the mass-specific magnetic susceptibility is determined by the content of magnetic minerals of different origin (Thompson and Oldfield 1986). In our case it can be assumed that differences in values within the Ice Complex as well as in the Pingo sequence are caused mainly by changes in the mineralogical composition of rocks in the denudation area and probably in the hydrodynamic conditions of transport and accumulation of clastic compounds. Low values of the mass-specific magnetic susceptibility in layers with high organic carbon contents probably indicate that a reduction of magnetic iron oxides by gley processes has occurred in these slightly drained peaty tundra soils. Such low values of the mass-specific magnetic susceptibility of paleosol horizons in cold loess sequences was also reported in Alaska by Stone et al. (1990).

\section{Interpretation: a first sketch of landscape development}

Although many questions remain concerning the genesis of Ice Complex deposits and the interpretation of analytical results, we attempt an initial sketch of Late Quaternary development including our new field and analytical results (Fig. 8). This could be the first step for the reconstruction of the Late Quaternary paleoenvironment in the study area of Bykovsky Peninsula. 
vertical profile sketch
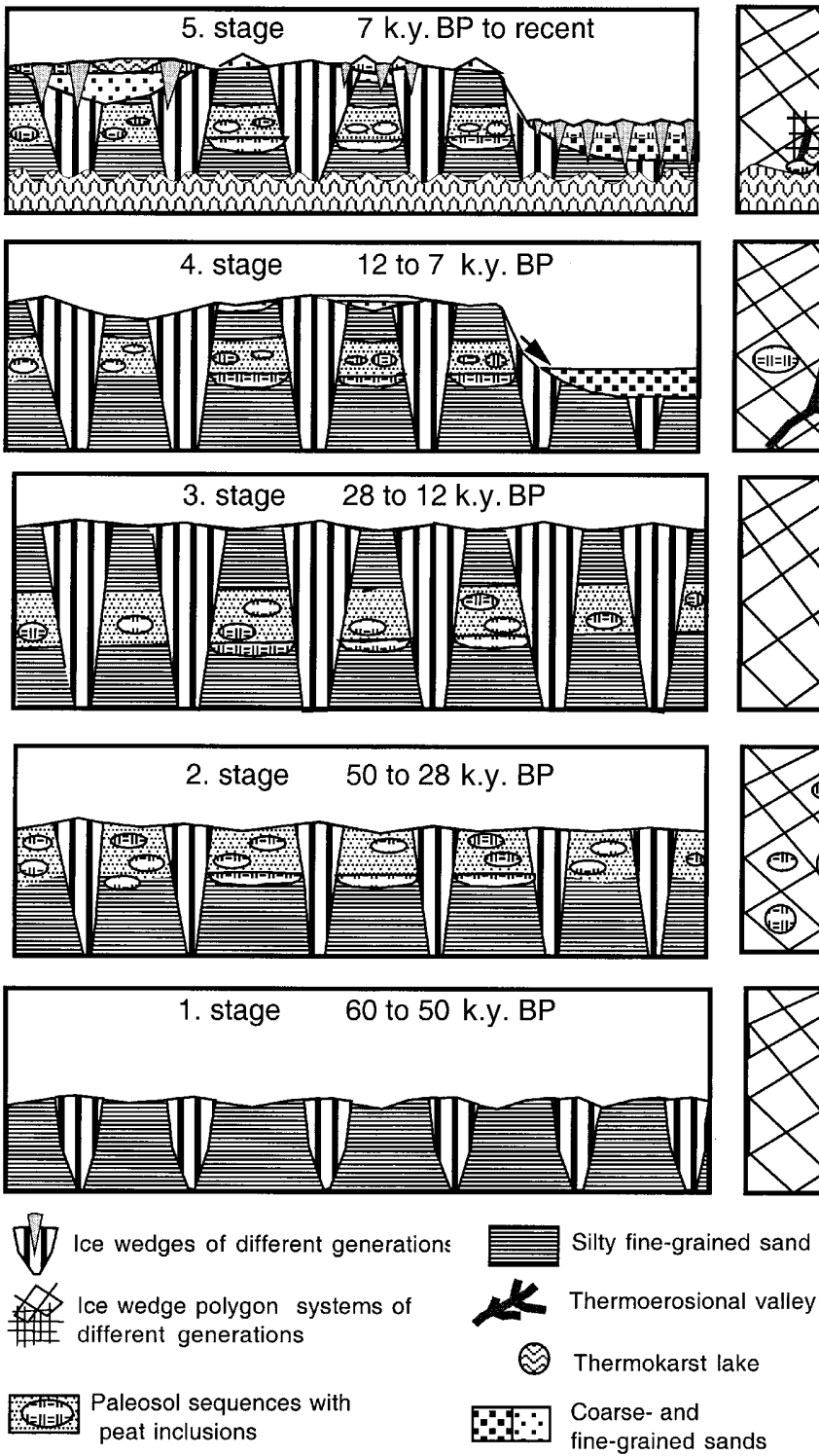

Paleosol sequences with peat inclusions

\section{surface sketch}
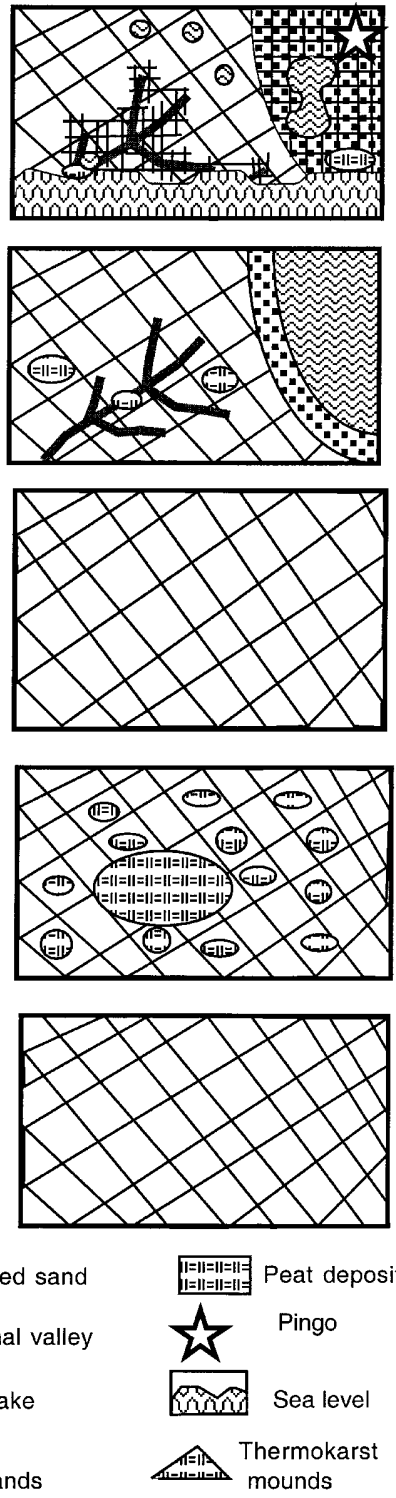

Fig. 8 Interpretation of the permafrost landscape evolution and the assumed environmental conditions in the study area during the Late Quaternary. First stage: formation of the lower Ice Complex level, +1-4 m (60-50 k.y. B.P.). Accumulation of silty fine-grained sand at an alluvial flood plain with polygonal pattern; formation of syngenetic ice wedges; weak soil formation and small accumulation of organic matter; stable drier conditions. Second stage: formation of the middle Ice Complex level, +9-22 m (50-28 k.y. B.P.). Accumulation of silty finegrained sand enriched with plant material on a poorly drained polygonal tundra plain; intensification of soil formation and intensive peat accumulation; unstable environmental conditions; continuation of ice wedge growth. Third stage: formation of the upper Ice Complex level, $+22-35 \mathrm{~m}$ (28 to $12 \mathrm{k} . \mathrm{y}$. B.P.). Accumulation of fine-grained silty sand on a poorly drained polygo-

The lower level of the Ice Complex is characterized by weak paleosol formation and few plant remains between approximately 60 and 50 k.y. B.P. Silty finegrained sand was deposited under subaerial conditions nal tundra plain by periodic runoff; decreasing of soil formation under dryer and more stable conditions; continuation of ice wedge growth. Fourth stage: formation of the uppermost cover on the Ice Complex, $+35-37 \mathrm{~m}$ and the sandy alas deposits, + 0.5-2 m (12 to 7 k.y. B.P.). Destruction of the Ice Complex and formation of big thermokarst depressions and taliks. Thermoerosion and formation of wide runoff valleys. Accumulation of coarser sandy deposits; lacustrine accumulation into thermokarst lakes; growing of trees at approximately 9 k.y. B.P. Fifth stage: formation of alas peats and valley deposits (7 k.y. B.P. recent); drying up of thermokarst lakes, refreezing of taliks, formation of pingos; proluvial slope processes; peat accumulation in alasses and runoff valleys; formation of new ice-wedge generations; local thermokarst processes, thermoabrasion on the coastal cliff; treatment of surface by recent nival processes

on an alluvial flood plain. Syngenetic ice wedges were formed and the environmental conditions were relatively dry and probably very cold. 
This stage was followed at approximately $50 \mathrm{k} . \mathrm{y}$. B.P. by an unstable period with strong variations in the environmental conditions. After an initial lacustrine phase and intensive soil formation, local thermokarst became active and peat was formed in some positions. The ice-banded cryostructure indicates several years of stable surface conditions, which were interrupted by several accumulation events. The repeated occurrence of buried soils and the variations seen in the analytical data reflect quite variable environmental conditions during this period. The growth of the large ice wedges continued without lengthy interruptions. This unstable stage ends with a rapid decrease of organic matter in the Ice Complex deposits by approximately 28 k.y. B.P.

The next stage, between 28 and 12 k.y. B.P., is characterized by relatively continuously drier and probably colder conditions without any strong soil formation and peat accumulation. The accumulation of silty fine-grained sand and the growth of large ice wedges continued during this time. According to Romanovsky et al. (1998), this landscape covered large portions of the flat Laptev Sea Shelf, which lay 40-100 $\mathrm{m}$ above sea level during the Late Pleistocene because of eustatic sea-level lowering.

Large changes in the environmental conditions during the Late Pleistocene-Holocene transition mark the next stage, between approximately 12 and 7 k.y. B.P. Extensive thermo-erosion and thermo-denudation occurred with the formation of large thermokarst lakes, taliks, and thermo-erosional valley systems. The formation of the Ice Complex came to an end and remains of trees in alas deposits dated approximately 9 k.y. B.P. indicate the amelioration of climate conditions.

The valleys and thermokarst depressions became filled with eroded material in the following period $(<7$ k.y. B.P.) and new ice-wedge systems were formed in these new sediments. Several pingos in alasses were created through talik refreezing. The filling process very often ended with peat accumulation between 4 and 1 k.y. B.P. In recent time local thermokarst processes, solifluction, and nival processes affected the landscape.

\section{Conclusion}

We attempt to subsume and compare our local results with the global scale climate evolution indicated by the marine isotope stages (MIS). The timing of the Siberian Arctic's periglacial evolution covers the past 60 k.y. (Middle Weichselian to Holocene), based on the ice-rich permafrost sequences studied on the Bykovsky Peninsula. This can be compared with the MIS 4 to 1 (Shackleton et al. 1990). We know that the radiocarbon timescale has large uncertainties in the range of 25-50 k.y. B.P. due to changes in cosmogenic isotope production and in the global carbon cycle, and is, therefore, unsuitable for comparisons within a few thousand years. Nevertheless, it can be used to place the lower level of the Ice Complex in or at the end of MIS 4. The long and mild MIS 3 follow MIS 4 until approximately 28 k.y. B.P., which corresponds with the middle level of the Ice Complex. For this period the Greenland ice cores GRIP and GISP 2 have many large and rapid isotope (and climatic) fluctuations (Dansgaard et al. 1993; Grootes et. al. 1993; Grootes and Stuiver 1997), known as Dansgaard/Oeschger events. Repeated alternations of warm episodes with strong North Atlantic Deep Water (NADW) formation and Atlantic northward heat transport and cold periods without such heat transport have been assumed in the MIS 3 (Grootes and Stuiver 1997). It is expected that the influence of the heat transport was less pronounced in the North Siberian Arctic far away from the North Atlantic. Therefore, we dare to consider the sequence of numerous peaty paleosols in the Ice Complex deposits as equivalent to the Dansgaard/Oeschger events in the Laptev Sea region. However, the dating is insufficient for more detailed comparison. Conversely, considerations of the evidence of changing climates from the ice cores provide support for the existence of alternating warm and cold phases during the period of Ice Complex formation. The age of the upper level of the Ice Complex approximately coincides with the MIS 2 cold period and corresponds to the Sartian time of the Russian Quaternary stratigraphy. The strong change in paleoenvironmental conditions in the study area approximately 12 k.y. B.P. could be interpreted as the Oldest Dryas-Bölling transition. After approximately 6 k.y. the early Holocene warm optimum had ended and a general cooling period started. The interpretation of paleoenvironmental archives studied in Late Quaternary ice-rich permafrost sequences in the Laptev Sea area thus fits generally into the global Late Quaternary history.

Acknowledgements The authors thank V. Tumskoy, T. Kuznetsova, A. Derevyagin, and S. Kuzmina from Moscow, H. Meyer from Potsdam, and I. Syromyatnikov from Yakutsk for their help during field work and numerous discussions on the results. We thank especially A. Sher from Moscow for handing over the supplemental samples in 1999 and for many hints during the preparation of this paper. Additional thanks to P. Overduin from Fairbanks for language review. This study was funded by the BMBF through the Russian-German research project "System Laptev Sea 2000." This is publication no. 1632 of the Alfred-Wegener Institute for Polar and Marine Research, in Bremerhaven and Potsdam.

\section{References}

Alekseev MN (1982) Problems of stratigraphy and paleogeography of the Quaternary of Yakutia. In: Geology of the Cenozoic of Yakutia. Yakutsk, Russia, pp 7-13 (in Russian)

Bunge A (1895) Die Lena Expedition 1881-1884. In: Tillo A (ed) Beobachtungen der russischen Polarstation an der Lenamündung. Expedition der Kaiserl. Russischen Geographischen Gesellschaft, St. Petersburg, pp 1-96 
Dansgaard W, Johnsen SJ, Clausen HB, Dahl-Jensen, D, Gundestrup NS, Hammer CU, Hvidberg CS, Steffensen JP, Sveinbjörndottir AE, Jouzel J, Bond G (1993) Evidences for general instability of past climate from 250 - kyr ice-core record. Nature 364:218-220

Eliseev VI (1977) Regularities of the Formation of Proluvium. Nedra, Moscow (in Russian)

Embleton C, King CAM (1975) Periglacial geomorphology: glacial and periglacial geomorphology, 2nd edn, 2nd vol. London, pp 1-203

French HM (1996) The periglacial environment, 2nd edn. Longman, Harlow, pp 1-341

French HM, Heginbottom JA (eds) (1983) Guidebook to permafrost and related features of the northern Yukon territory and Mackenzie delta, Canada. Proc 4th Int Conf on Permafrost, Fairbanks, 18-22 July, pp 1-186

Fukuda M (1994) Occurrence of Ice-complex (Edoma) in Lena River Delta Region and Big Lhyakovsky Island, High Arctic Eastern Siberia. In: Inoue G (ed) Proc 2nd Symp on the Joint Siberian Permafrost Studies between Japan and Russia, pp 5-13

Galabala RO (1987) Conditions of the formation of Late Quaternary plains in northern Siberia. In: Logachev NA (ed) Protsessy formirovaniya rel'efa Sibiri. Nauka, Novosibirsk, pp 63-68 (in Russian)

Galabala RO (1997) Pereletki and the initiation of glaciation in Siberia. Quaternary Int 41/42:27-32

Gravis GF (1969) Slope deposits in Yakutia. Nauka, Moscow, pp 1-128

Grigoryev MN (1993) Cryomorphogenesis of the Lena Delta mouth area. Permafrost Inst Academy of Science USSR, Siberian Dep, Yakutsk, pp 1-176 (in Russian)

Grootes PM, Stuiver M (1997) Oxygen 18/16 variability in Greenland snow and ice with $10^{-3}$ - to 105 -year time resolution. J Geophys Res 102:26455-26470

Grootes PM, Stuiver M, White JWC, Johnsen S, Jouzel J (1993) Comparison of oxygen isotope record from GISP2 and GRIP Greenland ice cores. Nature 366:552-554

Grosswald MG (1998) Late-Weichselian ice sheets in Arctic and Pacific. Siberia. Quaternary Int 45/46:3-18

Gundelwein A (1998) Eigenschaften und Umsetzung organischer Substanz in Nordsibirischen Permafrostböden. Hamburger Bodenkundl Arb 39:1-162

Ivanov MS (1984) Cryogenic structure of Quaternary deposits of the Lena-Aldan-Depression. Nauka, Novosibirsk, pp 1-125 (in Russian)

Kaplina TN (1982) History of permafrost of northern Yakutia in the late Cenozoic period. In: History of development of permafrost in Eurasia. On the example of separate regions. Nauka, Moscow, pp 153-181 (in Russian)

Katasonov EM (1954) Lithology of the perennially frozen Quaternary deposits (cryolithology) of the Yana Lowland. Doctoral thesis, Obruchev Permafrost Institute, Moscow

Katasonov EM (1978) Permafrost-facies analysis as the main method of cryolithology. In: Sange FJ, Hyde PJ (eds) Proc 2nd Int Conf on Permafrost, pp 171-176

Kunitsky VB (1989) Cryolithogenesis of the lower Lena Permafrost. Inst Acad of Sci USSR, Siberian Dep, Yakutsk, pp 1-162 (in Russian)

Kunze H, Roeschmann G, Schwertfeger G (1994) Bodenkunde. Ulmer, Stuttgart, pp 1-424

Meyer H, Dereviagin A, Siegert C, Hubberten HW (2000) Hund O-isotope und Hydrochemie von Grundeis Ein spätquartäres Klimaarchiv für NE-Sibirien. Terra Nostra 20002:81-83

Nadeau MJ, Schleicher M, Grootes PM, Erlenkeuser H, Gottdang A, Mous DJW, Sarnthein JM, Willkomm H (1997) The Leibniz Labor facility at the Christian-Albrecht-University, Kiel, Germany. Nucl Instr Methods Phys Res B123:22-30

Nadeau MJ, Grootes PM, Schleicher M, Hasselberg P, Rieck A, Bitterling M (1998) Sample throughput and data quality at the Leibniz Labor AMS facility. Radiocarbon 40:239-245
Nagaoka D (1994) Properties of Ice Complex deposits in eastern Siberia. Proc of the 2nd Symp on the Joint Siberian Permafrost Studies between Japan and Russia, pp 14-18

Nagaoka D, Saijo K, Fukuda M (1995) Sedimental environment of the Edoma in high Arctic eastern Siberia. Proc of the 3rd Symp on the Joint Siberian Permafrost Studies between Japan and Russia, pp 8-13

Pfeiffer EM, Jansen H (1993) $\delta^{13}$ C-analysis of permafrost soil samples of NE-Siberia. Proc of the Joint Russian-American seminar on Cryopedology and Global Change, pp 297-302

Popov AI (1953) Specific features of lithogenesis in the alluvial planes under cold climate conditions. Izvestiya AN USSR Ser Geogr 2 (in Russian)

Romanovsky NN (1993) Fundamentals of the cryogenesis of the Lithosphere. University Press, Moscow, pp 1-336 (in Russian)

Romanovsky NN, Gavrilov AV, Kholodov AL, Pustovoit GP, Hubberten H-W, Niessen F, Kassens H (1998) Map of predicted offshore permafrost distribution on the Laptev Sea Shelf. Proc of the 7th Int Permafrost Conference, pp 967-972

Rozenbaum GE (1981) Special features of lithogenesis of the alluvial planes in the Eastern Subarctic as related to the problem of the Ice (Yedoma) Complex. In: Problems of cryolithology, vol 9. University Press, Moscow, pp 87-100 (in Russian)

Schachtschabel P, Blume HP, Brümmer G, Hartge KH, Schwertmann U (1992) Lehrbuch der Bodenkunde. Enke, Stuttgart, pp 1-491

Schlichting E, Blume HP, Stahr K (1995) Bodenkundliches Praktikum. Blackwell, Berlin, pp 1-295

Schliesser GH (1995) Parameters determing carbon isotope ratios in plants. In: Frenzel B (ed) Problems of stable isotopes in tree-rings, lake sediments and peat bogs as climate evidence for the Holocene. Paleoclimate Res 15:71-96

Shackleton NJ, Berger A, Peltier WA (1990) An alternative astronomical calibration of the Lower Pleistocene timescale based on ODP Site 677. Earth Sci 81:251-261

Sher AV, Kaplina TN, Ovander MG (1987) Unified Regional Stratigraphic Chart for the Quaternary deposits in the YanaKolyma Lowland and its mountainous surroundings. Explanatory Note. In: Decisions of Interdepartmental Stratigraphic Conference on the Quaternary of the East USSR, Magadan, 1982. USSR Academy of Sciences, Far-Eastern Branch, North-Eastern Complex Research Institute, Magadan, USSR, pp 29-69 (in Russian)

Sher A, Parmuzin I, Bortsov A (2000) Ice Complex on the Bykovsky Peninsula. Rep Polar Res 354:169-182

Siegert C, Schirrmeister L, Kunitsky V, Dereviagin A, Krbetschek M, Kusnetsova T, Kuz'mina S, Meyer H, Sher A, Tumskoy V (1999) Paleoclimate signals in ice-rich permafrost. In: Rachold V, Grigoryev MN (eds) Russian-German Cooperation System Laptev Sea 2000: The Lena Delta 1998. Rep Polar Res 315:145-259

Slagoda EA (1991) Microstructure features of the deposits of ice complexes in northern Yakutia (by the example of Bykov Peninsula). In: Gilichinskiy DA (ed) Kriologiya pochv. Pushchino, IPFS PNTs AN SSSR, pp 38-47 (In Russian)

Slagoda EA (1993) Genesis and microstructure of cryolithogenic deposits at the Bykovsky Peninsula and the Muostakh Island. Dissertation, RAS Sibirian Section, Permafrost Institute, Yakutsk, pp 1-218 (in Russian)

Stone DB, Beget JE, Crumley S (1990) Magnetic studies of the Fairbanks (Alaska) loess deposits: Do they give a record of ancient climate changes? Abstr Int Symp Quaternary Stratigraphy and Events in Eurasia and Pacific Region 2:125

Stuiver M, Polach HA (1977) Discussion: Reporting of 14C data. Radiocarbon 19:355-363

Stuiver M, Reimer PJ, Bard E, Beck JW, Burr GS, Hughen KA, Kromer B, McCormac FG, Pflicht J, Spurk M (1998) INTCAL98 radiocarbon age calibration, 24,000-0 cal B.P. Radiocarbon 40:1041-1083 
Thompson R, Oldfield F (1986) Environmental magnetism. Allen and Unwin, Boston, pp 1-227

Tomirdiaro SV, Chernenky BI (1987) Cryogenic deposits of East Arctic and Subarctic. AN SSSR Far-East-Science Center, pp 1-196 (in Russian)

Tomirdiaro SV, Arslanov KA, Chernenkiy BI, Tertychnaya TV, Prokhorova TN (1984) New data on formation of loess-ice sequences in northern Yakutia and ecological conditions of mammoth fauna in the Arctic during the late Pleistocene. Dokl AN SSSR 278:1446-1449 (in Russian)

Vasil'chuk YuK, Vasil'chuk AC (1997) Radiocarbon dating and oxygen isotope variations in Late Pleistocene syngenetic ice wedges, northern Siberia. Permafrost Periglacial Processes $8: 335-345$
Welker JM, Wookey PA, Pearson AN, Press MC, Callaghan TV, Lee JA (1993) Lead carbon isotope discrimination and vegetative responses of dryas octopetala to temperature and water manipulation in a high arctic polar semi-desert, Svalbard. Oceologia 95:463-469

Welker JM, Heaton THE, Spiro B, Callaghan TV (1995) Indirect effect of winter climate on the $\delta^{13} \mathrm{C}$ and $\delta \mathrm{D}$ characteristics of annual growth segments in the long-lived, arctic plant Cassiope tetragona: a preliminary analysis. In: Frenzel B (ed) Problems of stable isotopes in tree-rings, lake sediments and peat-bogs as climatic evidence for the Holocene. Paläoklimaforschung 15:105-119 